\title{
CORAGEM DA VERDADE E PERFORMATIVIDADE CÍNICO-QUEER EM TATUAGEM, O FILME
}

\section{André Luiz dos Santos Paiva ${ }^{1}$}

Resumo: No presente artigo discute-se a performatividade enquanto modalidade de coragem da verdade a partir do filme Tatuagem. Apresenta-se o conceito de coragem da verdade, com foco em sua modalidade cínica. Articula-se o conceito de coragem da verdade cínica com o de performatividade em Judith Butler, defendendo-se que é a partir da performatividade que a coragem da verdade é exercitada no discurso de Tatuagem. Por fim, a partir de uma leitura cínico-queer da cena escolhida, defende-se que o discurso acerca da utopia do cu apresentado no discurso filmico é o maior ponto de inflexão entre filosofia cínica e pensamento queer.

Palavras-Chave: Coragem da verdade; Cinismo; Estudos queer.

\begin{abstract}
This article discusses performativity as a modality of courage of truth, starting from the movie Tatuagem. The concept of courage of truth is presented, focusing on its cynical modality. The concept of cynical courage of truth is articulated with that of performativity in Judith Butler, arguing that it is from the performativity that the courage of truth is exercised in the discourse of Tatuagem. Finally, from a cynical-queer reading of the chosen scene, it is argued that the discourse about the ass' utopia presented in the filmic discourse is the most striking point of inflection between cynical philosophy and queer thought..
\end{abstract} Keywords: Courage of truth; Cynicism; Queer studies.

\section{Introdução}

No presente artigo discute-se a performatividade enquanto modalidade de coragem da verdade tendo como ponto de partida o filme Tatuagem (Direção: Hilton Lacerda, 2013), mais especificamente uma das cenas de apresentação do grupo de teatro fictício do filme Chão de Estrelas na qual são defendidas, através da performance artística do grupo, as possibilidades utópicas do cu.

No momento inicial do artigo apresenta-se, apoiando-se principalmente nos dois últimos cursos ministrados por Foucault $(2010,2011)$ no Collège de Fran- 
ce, o conceito de parresía ou coragem da verdade, com foco em sua modalidade cínica, corrente de pensamento que Foucault mais se ateve nas obras citadas. Posteriormente, articula-se o conceito de coragem da verdade cínica com o de performatividade em Butler $(2008,2002,1997)$, defendendo-se que é a partir da performatividade que a coragem da verdade é exercitada no discurso de Tatuagem, o que possibilita uma releitura da conclusão foucaultiana de que não é possivel o exercício da coragem da verdade a partir dos atos performativos.

Por fim, a partir de uma leitura cínico-queer da cena escolhida possibilitada pelo encontro entre as concepções filosóficas dos cínicos antigos e as discussões contemporâneas construídas pelos estudos queer, defende-se que o discurso acerca da utopia do cu apresentado no discurso fílmico é o ponto de inflexão mais marcante entre a filosofia cínica e o queer, concluindo-se que o corpo ingovernável que emerge no discurso fílmico guarda correlações importantes com a forma com que o corpo foi utilizado pelos cínicos e é experienciado pelos queers.

\section{Alguns apontamentos gerais sobre Tatuagem, o filme}

Tatuagem é uma obra que pode ser inserida no contexto de uma produção queer que desponta no cenário cinematográfico nacional de pós-retomada, em especial no cinema pernambucano, marcado por certa liberdade e ousadia estética; inserção de aspectos políticos não vinculados a ideologias específicas fixas (NOGUEIRA, 2009); e uma forma de produção baseada no que Nogueira (2014) denomina de brodagem, formato de parcerias que o cinema de Pernambuco tomou para si e que muito contribui para que seus filmes não se dispersem tanto no que se refere às temáticas e estética, diferentemente do contexto geral nacional. Mesmo assim, é possivel afirmar que a obra possui características muito específicas que a diferencia de outras produções nacionais, tanto do período da pós-retomada como de outros momentos da cinematografia brasileira:

Tatuagem (2013, Hilton Lacerda) de certa forma se destoa por uma forma narrativa mais clássica e um apelo que atinge um público maior, comprovado por sua bem-sucedida carreira comercial nos cinemas brasileiros, além dos vários prêmios recebidos. Ainda assim, é passivel de inúmeros debates, ao apresentar o corpo como ferramenta de resistência máxima e melhor acabada aos conflitos da sociedade e da arte em si, através de suas várias possibilidades: o embate físico, a relação sexual - a reprodução incluída aí - , a arte performática, o realizar técnico, etc. (LOPES e NAGIME, 2015, p.16).

Nesse sentido, o filme se vale de características gerais do cinema da pós-retomada, bem como do cinema de temáticas relacionadas a gênero e sexualidade, 
apesar da obra não se resumir a essa última categoria. No filme, no campo dos sentidos, opera-se um movimento de fluidez identitária encontrado no cinema de gênero (LOPES, 2006) e no New Queer Cinema (LOPES; NAGIME, 2015) e, além desse aspecto, "uma estética híbrida, intertextual, transemiótica, multimidiática, em vez da busca de especificidade de uma linguagem cinematográfica" (LOPES, 2006, p. 384), apropriando-se do que Barros (2014) denomina do "tudo vale" (p.184) quando se refere às produções do período da pós-retomada.

A estética de Tatuagem pode ser caracterizada em muitos momentos como camp. "O camp se situa no campo semântico de ruptura entre alta cultura e baixa cultura, como o kitsch, o trash e o brega. Como comportamento, a palavra remete à fechação [...]" (LOPES, 2006, p. 384-5). Essa "fechação" cai muito bem ao New Queer Cinema, bem como pode ser muito bem apropriada pelas obras do cinema da pós-retomada. É essa fechação que impulsiona o estabelecimento de uma relação outra com Tatuagem, de acordo com o que Lopes (2006) afirmou sobre o cinema com temática de gênero de forma geral: "Não podemos desviar o olhar, não podemos fingir que não vemos. Tudo está lá, direto, na nossa cara: o preconceito e a alegria. Não há conciliação com o público nem com a sociedade" (p. 387), há exigência de uma maior abertura estética e analítica aos que fruem as obras e aos que as analisam enquanto objeto de estudo teórico.

\section{Coragem da verdade e filosofia cínica}

Michel Foucault (2010, 2011), em seus dois últimos cursos ministrados no Collège de France, O governo de si e dos outros - 1982-1983 (2010) e A coragem da verdade - 1983-1984 (2011), discute as manifestações da parresía ou "coragem da verdade" na filosofia e vida dos filósofos antigos. Ele expõe que "um dos significados da palavra grega parresía é o 'dizer tudo', mas na verdade ela é traduzida, com muito mais frequência, por fala franca, liberdade de palavra, etc” (2010, p.42), sendo a instituição dessa forma corajosa de enunciado um dos elementos mais importantes do pensamento filosófico antigo, apesar de raras vezes ser um conceito tomado como central nas discussões que ocorriam nesse período.

Segundo Foucault (2010), "há parresía quando o dizer-a-verdade se diz em condições tais que o fato de dizer a verdade, e o fato de tê-la dito, vai ou pode ou deve acarretar consequências custosas para os que disseram a verdade" ( $p .55)$, sendo esse o principal elemento diferenciador das outras formas de enunciação que podem vir a ocorrer nas quais a questão da verdade se impõe. Assim, antes da questão do falar livremente, a ênfase se dá na instituição da necessidade da coragem no ato enunciativo, que, apenas através dela, pode ser considerado parresiástico. Além do elemento da coragem, outro aspecto importante na parresía é que nela "não apenas se fala livremente e se diz tudo o que se quer, mas [...] há também essa ideia de que se diz o que efetivamente se pensa, aquilo em que 
efetivamente se acredita" (FOUCAULT, 2010, p. 171).

Esse retorno de Foucault à filosofia antiga de forma geral, e à ideia de parresía especificamente, se insere de forma direta em seu percurso intelectual de questionamento acerca da produçõe das verdades em diferentes contextos. Assim, pode-se afirmar que a grande questão perseguida pelo autor se relacionou à produção dos enunciados tidos por verdadeiros num movimento de produção de uma história da verdade (WELLAUSEN, 1996).

Essa mudança de foco impõe uma ética específica na manifestação da coragem da verdade, que se atrela de forma decisiva à produção de um modo de vida. O sujeito, em suas relações com os outros, lança-se num ato de liberdade que é o definidor do seu estatuto enquanto sujeito de enunciado nas manifestações da parresía, de forma que o mais importante nessa enunciação é a coragem enquanto virtude ética que o sujeito exerce no próprio ato de falar e dizer a verdade (WELLAUSEN, 1996). Será essa ética que vinculará a parresía e produção de modos de vida, dado que, como afirma Gros (2004), "é a vida, e não o pensamento, que é passada ao fio da navalha da verdade" (p. 163) no enunciado parresiástico.

No curso proferido em 1983, O governo de si e dos outros, Foucault (2010) distinguirá dois tipos de manifestação da coragem da verdade: a parresía política e a parresía filosófica. No primeiro caso, a parresía se institui enquanto uma estrutura política, de forma que a coragem da verdade é exercitada por um cidadão em relação ao governante. Assim, esse falar a verdade se refere à direção da cidade, à sua governabilidade, no qual um sujeito de enunciado se coloca em risco perante o soberano para exercer a fala franca a esse. No entanto, não é apenas no âmbito de uma política instituída que a parresía poderá ser exercida. Sobre isso Foucault (2010, p. 117) afirma:
A parresía é um ato diretamente político que é exercido, seja peran- te a assembleia, seja perante $\circ$ chefe, $\circ$ governante, o soberano, $\circ$ tira- no, etc. É um ato político. Mas, por outro lado, a parresía [...] também é um ato, uma maneira de falar que se dirige a um indivíduo, à alma de um indivíduo, e que diz respeito à maneira como essa alma vai ser formada.

Essa passagem da parresía das coisas referentes à gestão da cidade à alma do indivíduo constitui uma abertura para ampliar as possibilidades do exercício da coragem da verdade, pois, através dela não será apenas possivel pensar o exercício corajoso dos enunciados com a finalidade de fazer melhor caminhar as coisas públicas, mas, também, como um investimento na construção de uma estética da existência específica. Foucault $(2010,2011)$ denomina essa coragem da verdade exercida sobre as almas dos homens como parresía filosófica.

A parresía filosófica dá centralidade a uma ética-estética da existência, de for- 
ma que "o objetivo do dizer-a-verdade é portanto menos a salvação da cidade do que o éthos do indivíduo" (FOUCAULT, 2011, p. 58); será então sobre os sujeitos e suas relações consigo e com os outros, portanto relações éticas, que o parresiasta tentará intervir. A vida se mostra, assim, como objeto possível de beleza, e, nesse âmbito, as questões da "verdadeira vida" (FOUCAULT, 2011) e do cuidado de si necessário para a instituição de um outro modo de vida são exercitadas.

Foucault (2011, p. 145) afirma que "o tema da beleza da existência, da forma mais bela possivel a dar à sua existência, e o do exercício da parresía, da fala franca, estão diretamente ligados". Essas questões são colocadas, principalmente, na parresía socrática, que teria como imperativo o conhece-te a ti mesmo como norteador para o exercício da coragem da verdade e encontra na ironia sua forma mais marcante de manifestação. No entanto, não é apenas em Sócrates que a questão da estética da existência em sua relação com o exercício da fala franca, a parresía, se coloca. Foucault destaca ainda, dentre as formas de coragem da verdade encontradas no período antigo, a parresía dos filósofos cínicos.

O filósofo cínico é aquele que tem seu próprio modo de vida como manifestação da verdade. Essa manifestação da verdade se dá através do escândalo desse modo de vida, de forma que, para o exercício dessa parresía, o modo de vida é condição constituinte. Nessa expressão da coragem da verdade há a fala clara e direta, com usos de recursos inclusive considerados inferiores, como os xingamentos e expressões "baixas", tanto nos discursos quanto nos comportamentos. O cinismo coloca a questão da vida outra, de uma recolocação dos valores sociais e normativos com o intuito de construção de uma estética da existência que estabeleça uma relação do sujeito consigo e com os outros que tem como objetivo outro mundo possível (FOUCAULT, 2011). A relação do cinismo com o escândalo é, assim, marcante. A respeito dessa relação, Foucault (2011, p. 205) afirma:

Com o cinismo, temos uma terceira forma de coragem da verdade, distinta da bravura política, distinta também da ironia socrática. A coragem cínica da verdade consiste em conseguir fazer condenar, rejeitar, desprezar, insultar, pelas pessoas a própria manifestação do que elas admitem ou pretendem admitir no nível dos princípios. Trata-se de enfrentar a cólera delas dando a imagem do que, ao mesmo tempo, admitem e valorizam em pensamento e rejeitam e desprezam em sua própria vida. É isso o escândalo cínico. Depois da bravura política, depois da ironia socrática, teríamos, se vocês quiserem, o escândalo cínico.

A discussão que Foucault realiza em relação ao cinismo antigo insere-se, assim, dentro de seu trabalho mais amplo de pensar as relações entre sujeito e verdade, encontrando na filosofia cínica o momento de maior inflexão entre produção discursiva da verdade e a produção de modos de vida através da demanda cínica de desfiguração da "moeda" vigente no que se refere aos valores sociais contra os quais 
se colocavam nos campos filosóficos e políticos (FOUCAULT, 2011).

Para pensar a produção da coragem da verdade, Foucault debruçou-se sobre a filosofia cínica de forma geral, e, mais especificamente, sobre Diógenes, talvez - filósofo cínico de maior prestígio tanto em seu tempo quanto atualmente. De acordo com Navia (2009) é fácil identificar que, para Foucault, Diógenes tornou-se o exemplo máximo do filósofo que deu centralidade à produção da parresía, através da qual ele estabeleceu um comprometimento com o falar franco em qualquer circunstância admitindo para si os riscos que essa prática trazia.

\section{Coragem da verdade cínica e despudor}

O pensamento cínico dificilmente pode se enquadrar e ser analisado enquanto uma escola filosófica em sentido estrito (NAVIA, 2009). Isso porque essa perspectiva filosófica tinha como foco muito mais os modos de vida das pessoas que pretendiam apreender algo do cinismo para suas existências, do que construções teóricas a serem ensinadas através de conteúdos formais (DIAS, 2011). $O$ filósofo cínico é aquele para o qual, no ato de filosofar, é determinante, antes do discurso, seu modo de vida (DIAS, 2011), de forma que "[...] não devemos esperar encontrar um sistema filosófico, nem mesmo uma coleção convincente e bem arranjada de asserções filosóficas [no cinismo]" (NAVIA, 2009, p. 158), mas, ao invés disso, uma certa forma de viver que será característica desse movimento filosófico e através da qual o pensamento cínico verdadeiramente se manifestará. Esse modo de vida articula-se diretamente com a demanda cínica de repudiar e questionar os valores sociais vigentes em sua sociedade.

No cinismo, através de vestimentas rudimentares, pouca atenção em relação aos costumes e etiqueta e a reiteração propositada de atos de despudor, expressa-se, não apenas no campo das ideias mas também das práticas, o pensamento e postura política cínica. Essa relação intrínseca entre um modo "desavergonhado" (SOUSA, 2012) de viver e um tipo específico de pensamento filosófico é de extrema importância na compreensão do cinismo. Esse é o elemento constituinte e ponto central dessa experiência, através do qual é possivel fazer convergir a lógica e propósito do pensamento cínico antigo, bem como possibilita o vislumbre de alguma forma de unidade numa corrente filosófica que se mostrou mais plural que a maioria das correntes filosóficas de seu período devido a inexistência de dogmas fixados, principalmente através da escrita, característica que reforça o vínculo entre cinismo e prática, pois, se o campo das ideias e teorias era o espaço privilegiado do fazer filosófico para as demais correntes de pensamento

[...] para los cínicos, por el contrario, es necesario que la filosofía sea ante todo una expresión materialista-existencial, es decir, que los argumentos se sustenten y expresen en una determinada forma de vivir con fines eudemonistas, y no en un 
cúmulo de ideas sistematizadas que no contribuyan en lo más mínimo a la única búsqueda importante para el sabio: la de la felicidad. (SOUSA, 2012, p. 303)

No entanto, esse distanciamento, e até mesmo aversão, do cinismo à teoria pela teoria em detrimento dos conhecimentos que realmente poderiam ser úteis na vida prática e alcance da felicidade não torna essa corrente filosófica vazia, tampouco permite o questionamento de seu caráter filosófico. Ao contrário disso, era exatamente "o estilo de vida abnegado, o despudor aos convencionalismos sociais, aliados a uma singular moralidade, [que] davam ao cinismo um matiz excêntrico, um estilo único, com intensa profundidade filosófica" (DIAS, 2014, p. 216). O rigor filosófico cínico residia em sua radicalidade em pensar a filosofia enquanto forma de vida (DIAS, 2011), perspectiva essa que caracterizou os cínicos na antiguidade e que possibilita a identificação dos núcleos que constituem essa forma de pensamento filosófico.

personagem mais facilmente associado ao cinismo na história da filosofia antiga foi Diógenes, sobre o qual se encontram a quase totalidade de descrições acerca da filosofia cínica, dado que os filósofos cínicos não deixaram nada ou quase nada escrito que descrevesse e explicasse as concepções defendidas por eles (NAVIA, 2009). Na vida de Diógenes é possivel encontrar as características aqui discutidas como constituintes do cinismo em sua oposição às escolas filosóficas tradicionais:

La "vida filosófica" de Diógenes tiene poco de la seriedad y gravedad que solemos asociar a tan noble disciplina: nos enfrentamos con un tipo cuyo desparpajo es para dejar perplejo a cualquiera, un sujeto cuya capacidad de embromar a sus desprevenidos conciudadanos era, por lo menos, singular; en fin, un filósofo que bien podríamos llamar "cómico" e, inclusive, "payaso". (SOTO, 2010, p. 52).

A comicidade de Diógenes e dos demais filósofos cínicos relaciona-se com a forma como eles se colocavam nos lugares públicos, sempre desafiando as normas sociais vigentes em sua época, produzindo o riso e a fúria de seus contemporâneos (NAVIA, 2009). De acordo com Goulet-Cazé e Branham (2007), a palavra cínico pode ser traduzida literalmente por "à maneira de um cão" (p. 14). Esse adjetivo se referia à ausência de pudor dos filósofos cínicos; à naturalidade com a qual esses pensadores vivenciavam seus corpos e, mais importante; à maneira como se colocavam frente aos outros, num processo que valorizava sua maneira de pensar em detrimento das normativas sociais que eles consideravam como inúteis e como obstáculos ao alcance de uma vida feliz, objetivo maior da filosofia na concepção cínica.

A postura despudorada dos cínicos fazia parte de sua prática filosófica cons- 
tituindo-se enquanto elemento integrante da coragem da verdade por eles exercitada. O despudor cínico institui-se desde a tomada para si do insulto de cão, transformando a impopularidade ou má fama em uma máxima ética (SOUSA, 2012), que colocava os cínicos em oposição às formas de viver de sua época. Nesse sentido,

La desvergüenza como máxima ética no es [...] exclusivamente diogénica, sino que corresponde al espíritu de la filosofía cínica, además de ser la semilla del desarrollo de la pharresía, o franqueza, esa genial libertad de palabra que caracteriza a los cínicos, esa elocuencia sin miramientos que ataca como el mordisco de un perro o advierte como su ladrido. (SOUSA, 2012, p. 310).

Tomar a maneira de cão como semente da parresía exercitada pelos filósofos cínicos nos leva ao vislumbre de uma prática filosófica que rompe com a ideia de humanidade predominante. Assim, o autoproclamar-se cão reflete a oposição do cinismo ao instituído social, colocando-o no lugar de uma inadaptação constitutiva de suas experiências, de forma que o cinismo pode ser visto como uma "[...] filosofia de los incorregibles, de los inadaptados, de los desposeídos, de los anormales, de los pequenos [...]" (SOUSA, 2012, p. 310).

\section{Performatividade cínico-queer e o discurso filmico de Tatuagem}

A partir do vislumbre do performativo subversivo no filme proponho aqui uma aproximação entre essa expressão do performativo e a coragem da verdade em sua modalidade cínica. A partir da repetição subversiva exercitada em Tatuagem há a produção de um discurso, e esse discurso, através principalmente das paródias apresentadas pelo grupo Chão de Estrelas se coloca de forma corajosa no contexto do filme, sendo assim paródias subversivas. Acerca da paródia Butler (2008, p. 198) afirma:

A paródia não é subversiva em si mesma, e deve haver um meio de com-
preender o que torna certos tipos de repetição parodística efetivamen-
te disruptivos, verdadeiramente perturbadores, e que repetições são do-
mesticadas e redifundidas como instrumentos da hegemonia cultural.

A essa provocação de Butler (2008) lanço como possivel resposta a de que a paródia, a repetição subversiva das normas sociais, se mostra como disruptiva quando exerce a coragem da verdade, coragem essa que se relaciona não apenas com um enunciado, mas também com a relação que o sujeito do enunciado estabelece com sua verdade e a estética de vida que exercita através e a partir da parresía. 
Foucault (2010) afirma que há incompatibilidade entre performatividade e a manifestação da coragem da verdade. No entanto, a partir da teoria da performatividade de Judith Butler (2008), que amplia as formas de pensar o performativo se apropriando, entre outros autores, inclusive do pensamento foucaultiano, defendo que, no filme Tatuagem, é justamente no ato performativo que a coragem da verdade, a parresía, se manifesta de forma mais clara e contundente no discurso fílmico.

Para Foucault (2010), que entende a parresía como uma forma de veridicção, essa incompatibilidade entre os atos performativos e a coragem da verdade se estabelece por três razões principais: a primeira é que nos atos performativos, ao haver uma situação dada, ocorrendo a enunciação de determinado discurso por parte do sujeito instituído com o poder dessa enunciação, um determinado efeito, necessariamente, se seguirá, efeito esse já conhecido de antemão,

[...] ao passo que, ao contrário, na parresía, qualquer que seja o caráter habitual, familiar, quase institucionalizado da situação em que ela se efetua, o que faz a parresía é que a introdução, a irrupção do discurso verdadeiro determina uma situação aberta, ou antes, abre a situação e torna possivel vários efeitos que, precisamente, não são conhecidos. (FOUCAULT, 2010, p. 60).

Nesse sentido, a diferença entre os atos performativos e a parresía será a abertura ao risco encontrada na segunda. A segunda razão para a incompatibilidade entre os atos performativos e a coragem da verdade para Foucault (2010) é que, na parresía, há um compromisso do sujeito do enunciado com o que enuncia, o que é denominado pelo autor de pacto parresiástico, ou seja, - sujeito expressa uma verdade na qual realmente acredita e estima verdadeiramente. Isso não necessariamente será verdade nos atos performativos, uma vez que estes não exigem que o sujeito do enunciado acredite no que diz, mas apenas que, estando instituído de um poder enunciador, seu enunciado tenha estatuto de verdade e efeitos específicos.

Já a terceira razão apontada por Foucault (2010) se refere ao estatuto social do enunciado, pois, diferentemente do que pode ser encontrado nos atos performativos, "não encontramos no cerne da parresía o estatuto social, institucional do sujeito, encontramos sua coragem" (p. 63), ou seja, o espaço enunciativo do sujeito é deixado em segundo plano em relação ao que este enuncia, e, nesse sentido, o estatuto do sujeito pouco ou nada importa frente a verdade que este expõe publicamente, correndo os riscos dessa exposição.

Essa forma de pensar os atos performativos, no entanto, pode ser reavaliada a partir da teoria da performatividade desenvolvida posteriormente por Butler 
(2008). As discussões acerca da performatividade desenvolvidas por essa autora se localizam no âmbito dos estudos de gênero e sexualidades, no entanto, é possivel, a partir da analítica da cena de Tatuagem aqui desenvolvida, ampliar o campo de exercício desse conceito, algo já apontado como uma alternativa pela própria Butler (2008).

O conceito de performatividade nessa autora dialoga em alguma medida com a teoria dos atos performativos desenvolvida por Austin (1990). Para esse autor, os atos performativos estabelecem a possibilidade de outra concepção de linguagem que, estando atrelada à performatividade, se vincula aos usos em contextos reais da língua, e não a uma linguagem ideal. Austin (1990) realiza a distinção entre os atos de fala constativos e performativos, sendo os primeiros atos que descrevem e os segundos atos que fazem, praticam algo. Nesse sentido, nos atos performativos a própria fala realiza a ação através de um enunciado, alimentando-se e criando ao mesmo tempo a realidade social.

Essa relação entre o ato performativo a criação de realidades é a maior contribuição de Austin (1990) à ideia de performatividade posteriormente desenvolvida por Butler (2008). No entanto, como destaca Pinto (2002) ao discutir as influências do pensamento de Austin na performatividade tal como pensada por Butler, no encontro com o conceito a autora inseriu a questão do corpo. Dessa forma, ao se falar em performatividade em Butler (2008) fala-se de um sujeito de linguagem que não apenas enuncia e cria realidades, mas que também é criado e materializa-se enquanto sujeito a partir do performativo, forjando, reiterando e subvertendo a produção da linguagem e dos próprios corpos por ela possibilitados enquanto espaços de enunciação.

$\mathrm{Na}$ ideia de performatividade defendida por Butler (2008) encontramos alguns aspectos de divergência ou complementaridade em relação a forma como Foucault (2010) vislumbra os atos performativos. A que mais interessa aqui se refere ao vislumbre da performatividade como repetição de atos normativos e, também, sua possibilidade de repetição parodística, subversiva, o que rompe com a concepção foucaultiana que percebe os atos performativos em oposição à parresía pela impossibilidade de ruptura que os primeiros teriam ao vê-los estritamente como repetição do instituído.

É importante destacar que a ideia de performatividade não está restrita a uma performance artística, mas, ao contrário, encontra seus espaços de expressão na produção da própria realidade social, tal como Butler $(2002,2008)$ analisa no âmbito específico dos gêneros e sexualidades. A performatividade nesse pensamento seria então a repetição de atos e gestos que todos os sujeitos exercitam em suas vidas nas mais diversas situações, e não apenas em situações ritualizadas como aponta Foucault (2010). Dizem respeito, ao contrário, de gestos cotidianos. Assim, não é o fato de tratarem-se de performances artísticas o que me move para a análise filmica de Tatuagem apoiando-me, 
em parte, na teoria da performatividade de Judith Butler $(2008,1997)$, mas a possibilidade de reapropriação das normas sociais, as citações e recitações parodísticas que tornam essas performances subversivas no contexto do filme de forma geral, e na cena aqui analisada, especificamente.

\section{Corpo e performatividades anais: entre o cínico e o queer}

O desenvolvimento do conceito de performatividade se dá no âmbito dos estudos queer, que surgiram entre o fim da década de 1980 (SÁEZ, 2007) e início da década de 1990, inicialmente nos Estados Unidos, e dialogam com o feminismo de terceira onda, com os estudos culturais e pós-estruturalistas e com os estudos subalternos (SOUZA e BENETTI, 2015; GARCÍA, 2007). O queer apropria-se de um insulto, que poderia ser traduzido por "bicha", "viado", estranho ou anormal, para instituir outra relação com os processos de subalternidades (PELÚCIO, 2014; LOURO, 2001; COLLING, s/a).

O queer surge inicialmente enquanto política de questionamento e enfrentamento para apenas posteriormente consolidar-se enquanto campo de reflexão teórica (PELÚCIO, 2014; MISKOLCI, 2012). Nesse processo de construção de prática e pensamento alguns fatores foram determinantes para a emergência e a consolidação das políticas e estudos queer, dentre os principais encontra-se a descoberta e consequente crise gerada pela aids, notadamente nos meios homossexuais e de divergência sexual-genérica; a crítica aos movimentos gays e lésbicos que passaram a ter uma feição mais normatizada com foco na ideia de inclusão; e o questionamento do feminismo tradicional, que se consolidou enquanto um movimento de mulheres brancas de classes média e alta, o que invisibilizava experiências de outras mulheres que reivindicavam uma perspectiva interseccional para o movimento feminista (SÁEZ, 2007).

Esse pensamento em muitos momentos converge com o a concepção filosófica dos cínicos, de forma que é possivel uma aproximação desses campos teórico-práticos com a cena aqui analisada tomando como referência o corpo e as normativas sociais que o atingem, problematizadas em alguma medida tanto pelo cinismo como pelos estudos queer. $O$ ponto mais intenso de inflexão entre a filosofia cínica, o filme Tatuagem e os estudos queer pode ser encontrado na enunciação da utopia do cu defendida no discurso fílmico da obra. Essa apropriação escandalosa e subversiva do cu institui um lugar outro de enunciados que desafia a normatividade ético-estética do contexto do filme, bem como nos incita a pensar e repensar essas expressões de possibilidades subversivas na realidade social. $O$ exercício de reapropriar-se de um insulto ou xingamento é constitutivo tanto da parresía cínica, quanto da perspectiva queer, e é esse mesmo exercício que encontramos no discurso fílmico de Tatuagem.

Essa possibilidade de análise do discurso fílmico parte de uma concepção do 
corpo que o pensa enquanto algo imerso em processos desejantes maquínicos (DELEUZE e GUATTARI, 2010), que se desarranjando e se desorganizando encontra-se e perde-se de seus fluxos criando novas possibilidades de discurso que, necessariamente, se atrelam a modos de vida sempre temporários e precários que não estabelecem territórios fixos dos quais retirar regras gerais, tampouco permite o desejo de encontro com um universal, mas, ao contrário, aponta sempre para a possibilidade da multiplicidade. É nessa perspectiva que o cu emerge no discurso fílmico de Tatuagem, e se, como defendem Deuleuze e Guattari (2010), o cu foi o primeiro órgão a ser privatizado pelo sistema capitalista, no discurso filmico ele emergirá enquanto possibilidade utópica de transformação social e enunciação corajosa da verdade, num movimento estético-político que em muito se aproxima da filosofia cínica e estudos queer.

Pensar uma utopia do cu é pensar na construção de um mundo outro, demanda cínica por excelência, e de uma desterritorialização dos sustentáculos das experiências normatizadas nas relações sócio-culturais, esse um dos objetivos das perspectivas queer. $\bigcirc$ cu emerge no contemporâneo como o recusado no âmbito social, e, por isso, pode ser reapropriado como espaço de questionamentos e subversões (SAEZ e CARRASCOSA, 2011). Esse movimento é realizado no discurso filmico de Tatuagem que institui a utopia do cu como instrumento de provocação e exercício da coragem da verdade. A utopia do cu pode ser assim o núcleo que traz a possibilidade de pensar os processos de performatividade, parresía cínica e estudos queer em suas relações desde um corpo (re)inventado a partir do cu.

O discurso acerca da utopia do cu surge de forma mais forte na performance apresentada pelo Chão de Estrelas ao som da polka do cu:

Tem cu que é amarrado

Tem cu escancarado

Tem cu muito seboso

Tem cu que é bem gostoso

Tem cu que é uma bomba, que quando peida zoa

Tem cu que sai da linha

E tem cu que é uma gracinha

Tem cu, tem cu, tem cu...

Tem cu para todos

Tem cu para mim

Tem cu para você

Tem cu para dar, cu pra vender

Tem cu que tem medalha

Tem cu do coronel, que traz felicidades a todos do quartel

Tem cu carente 
Tem cu que é de parente

Tem cu que é dos outros

E tem o cu da gente

Tem cu, tem cu, tem cu...

O papa tem cu

O nosso ilustre presidente tem cu

Tem cu a classe operária

E se duvidar até deus tem um onipresente, onisciente, onipotente cu

A única coisa que nos salva, a única coisa que nos une, a única utopia possível é a utopia do cu.

Nessa cena, na qual os integrantes do grupo fictício do filme cantam e dançam sem roupas dando destaque em seus movimentos às suas bundas, os aspectos cínico-queer no discurso fílmico são escrachados. Pode-se notar a instituição de uma corpo-política que toma para si a missão de questionar os valores hegemônicos em relação ao corpo e valores sociais. Diógenes, o principal filósofo associado ao cinismo antigo, afirmava que sua missão no mundo seria desfigurar a moeda dominante, num sentido de desfiguração das tradições filosófica, política e social de seu tempo, dessa forma, "armado com a metáfora da 'desfiguração' que ele próprio havia escolhido, Diógenes estava preparado para todo ato de 'despudor' e aceitava o seu papel como o daquele que escandaliza a sociedade" (GOULET-CAZÉ; BRANHAM, 2007, p. 35), sendo esse mesmo tipo de despudor que a performance do Chão de Estrelas apresenta, pois, apropriando-se de forma explícita e sem pudores do cu, eles investem numa possiblidade de corpo e desejo que rompe com o instituído.

Através da polka do cu o Chão de Estrelas lembra que todos têm cu, "se duvidar Imagem 1: Apresentação da Polka do cu

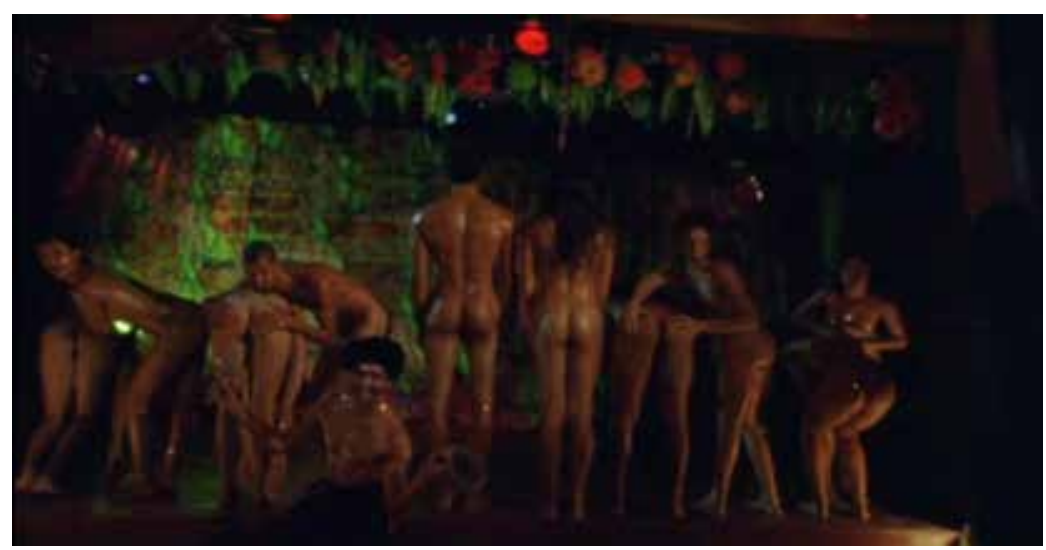

Fonte: Tatuagem, o filme (2013). 
até deus tem um onipresente, onisciente, onipotente cu". Essa apropriação do cu como espaço político tem sido exercitada pelo pensamento queer e certamente seria acompanhada por Diógenes e muitos dos cínicos com prazer, sendo estes os filósofos dos arrotos, peidos e masturbações públicas (NAVIA, 2009). Para essas perspectivas "el culo es um espacio político. Es un lugar donde se articulan discursos, prácticas, vigilancias, miradas, exploraciones, prohibiciones, escarnios, odios, asesinatos, enfermidades" (SAEZ e CARRASCOSA, 2011, p. 63), de forma que é na reapropriação desse espaço que se pode pensar uma corpo-política anal, ou, como sugere Preciado (2009), um terrorismo anal: "TERRORISMO ANAL = TERRORISMO KULTURAL" 2 (p. 144).

No entanto, para essa reapropriação é necessário coragem, pois não facilmente o espaço normativo aceitará que tem cu e que pode regozijar com ele, pois, se "tem cu que é amarrado", não há dúvida que o cu das normatividades sociais que inviabilizam a multiplicidade de modos de vida, produção dos desejos e corpos é um desses.

A coragem da verdade em sua modalidade cínica é assim exercitada no discurso filmico de Tatuagem através das performances do Grupo Chão de Estrelas que, colocando-se em risco, ousam até mesmo afirmar que "até o nosso ilustre presidente tem cu", bem como, "tem cu do coronel que traz felicidade a todos do quartel" em período de ditadura civil-militar, momento histórico no qual se passa a narrativa do filme. Essa coragem teriam os cínicos na antiguidade que ousaram afirmar o que os governantes não queriam ouvir, essa coragem tem muitos dos sujeitos que exercem uma política queer, ao desafiar as normas num período em que não vivemos numa ditadura enquanto regime político, mas que dissemina fascismo de forma capilar no meio social.

É através do discurso das performances no filme Tatuagem que ocorre a tentativa de modificar a moeda vigente. Os corpos nus que mostram seus cus em cena, de muitos formatos e ângulos diferentes, enunciam uma verdade corajosa que se manifesta a partir de um discurso que se efetiva enquanto prática, não podendo ser dissociada dela. Esse discurso não teme ser agressivo, pois é exatamente através do exagero e, por vezes, da violência, que ele poderá atingir seus objetivos. Assim, não é difícil afirmar que o discurso do grupo Chão de Estrelas pode ser definido como definiram Goulet-Cazé e Branham (2007, p. 36) o discurso cínico:

O discurso dos cínicos era caústico e agressivo; ele encurralava o interlocutor até este ser forçado a questionar a si próprio. É por isso que jogos de palavras, sarcasmo ácido e observações implacáveis são características de seus próprios métodos e do modo como eles foram representados por outros. 
Para a produção da coragem da verdade cínica e para os enunciados queer a questão da linguagem é central, e isso, desde os sentidos atribuídos aos próprios nomes com os quais esses movimentos se autodenominam. Long (2007) chama a atenção para os aspectos referentes a forma de apropriar-se da linguagem encontrada na vida e filosofia de Diógenes, o cínico:

Sua desfiguração da moeda incluía uma tentativa de estimular a reflexão reformando a linguagem. Ao rejeitar as denotações padronizadas de certos termos e ao renomear certas coisas, ele indicava a grande distância entre o discurso ético corrente e ao que ele considerava ser o significado natural dos termos (p. 48).

Essa forma de desfigurar a moeda através da desfiguração da linguagem é posta em prática no discurso fílmico de Tatuagem de forma geral, e na performance da Polka do cu em especial. $O$ que a performance aqui pensada proporciona é um questionamento da organização social que inviabiliza uma maior abertura dos corpos à multiplicidade. Esse processo ocorre através de práticas discursivas que impõem formas precisas de disciplina e controle dos corpos, seja através de recursos que incidem diretamente sobre os corpos enquanto materialidade, como no caso de contextos ditatoriais, como no que se passa o filme, seja através de recursos mais capilarizados que inviabilizam que a produção desejante atravesse os espaços sociais construindo linhas de fuga ativas aos processos molares nos quais nos encontramos imersos (DELEUZE; GUATTARI, 2010). Essa corpo-política de questionamento exercitada pela performance no filme Tatuagem garante que os desejos enquanto fluxos continuem escapando pelas brechas, através de outro estatuto de sujeito que, apropriando-se de seu espaço de abjeção, estabelece a possibilidade de manifestar a coragem da verdade de forma que:

[...] el sujeto que hasta ahora ha sido construido como abyecto (analizado, reducido a ano social) excede la injuria, no se deja contener por la violencia de los terminos que lo constituyen y habla, creando un nuevo contexto de enunciación y abriendo la posibilidad a formas futuras de legitimación. (PRECIADO, 2009, p. 159).

Assim, se é sobre o corpo que incidem as disciplinas e controles que cortam os fluxos desejantes, será também através dele que será possivel a produção de uma parresía cínica que dialoga em grande medida com as possibilidades abertas pelos estudos e políticas queer na contemporaneidade. $O$ corpo, no contexto da narrativa filmica de Tatuagem, mostra-se como o espaço privilegiado de enunciação, sendo através dele, de suas performances e falas, que se engendra um discurso disruptivo. O corpo é início, meio e fim de um processo que pode viabilizar o questionamento das normatividades sociais, sendo esta a mesma forma de 
apropriação do corpo utilizada pelos cínicos antigos, dado que também para eles

[...] o corpo é não só uma ferramenta para atacar inimigos ou chocar o público - embora sirva a esses dois propósitos eminentemente retóricos - mas também uma fonte de autoridade do cínico, sua justificativa para exercitar a parrhêsia. Ele o usa como a expressão visivel de sua isenção ao controle social, de sua imunidade à doxa ou opinião pública [...] (BRANHAM, 2007, p. 115).

É essa indiferença à opinião pública que marca as performances do Chão de Estrelas, de forma que suas produções, antes de desejarem obter os aplausos do público, estabelecem uma relação de fidelidade com o modo de vida exercitado pelos integrantes do grupo, na relação indissociável entre pensamento e prática encontrada na parresía. O "cu escancarado" que se expressa durante as performances é o mesmo que se abre à vida. A esta altura o cu ganha polifonia de sentidos, de forma que já não se fala apenas do cu que pode ser localizado materialmente na parte traseira de todos os seres humanos, mas sim a uma abertura dos corpos que, por sua universalidade, mostra-se sem gênero (PRECIADO, 2009) e sem funções específicas (SAEZ e CARRASCOSA, 2011), apontando para a potência de existência que atravessa todos os corpos.

\section{Considerações finais}

O discurso filmico de Tatuagem opera o questionamento do universal, e, para isso, a radicalidade cínico-queer é utilizada para desmascarar o falso que é tomado por verdadeiro, inclusive para mostrar que, no que se refere à produção desejante e de subjetividades, as ideias de falsidade e verdade são problemáticas. As expressões despudoradas mostram-se subversivas por produzirem um contraponto em relação às moralidades hegemônicas, tornando-se constitutivas da produção da parresía no discurso fílmico.

O momento no qual se produziram os discursos de Diógenes e dos demais cínicos e o momento no qual é produzido o discurso fílmico de Tatuagem são muito diferentes. No entanto, como sugere Foucault (2011), o cinismo em suas generalidades pode ser tomado como uma categoria transhistórica de análise. Assim, a emergência de corpos e subjetividades que questionam as normatividades de forma radical pode ser encontrada em diferentes momentos históricos, com facetas diferenciadas, mas, mesmo assim, ser associada à parresía cínica sempre que houver a ocorrência do que Branham (2007) denomina de corpo ingovernável, instrumento cínico de combate à falsidade dos códigos instituídos pela vida dita civilizada.

O corpo ingovernável dos cínicos é o mesmo corpo exercitado pelo Chão de Estrelas em suas performances. É através dele que ocorre a produção da par- 
resía, o questionamento do estatuto social vigente. $\bigcirc$ grupo estabelece assim uma forma de exercício performático da parresía que passa pela afirmação do cu como espaço de produção de enunciados subversivos, uma performatividade anal que se estabelece no discurso fílmico enquanto possibilidade de resistência biopolítica a partir de políticas do ânus, e "podríamos decir que las políticas del ano son contra-biopolíticas. Por tanto, políticas del cuerpo [...], cuerpo como plataforma relacional vulnerable, histórica y socialmente construida, cuyos límites se ven constantemente redefinidos" (PRECIADO, 2009, p.148).

A radicalidade do vislumbre do corpo como plataforma mutável e através da qual é possivel pensar uma forma outra de política atravessa o discurso filmico de Tatuagem, a filosofia cínica e os estudos e políticas queer. "Os cínicos usam as funções corporais como uma linguagem de protesto" (KRUEGER, 2007, p. 256), os queers apropriam-se da ideia de subalternidade (MISKOLCI, 2012) para repensarem e refazerem as formas de vislumbre e questionamento das normatividades através de uma corpo-política, ambos movimentos realizados pelo Chão de Estrelas.

Esses processos apontam para uma violação social que questiona os moldes e bases nas quais os processos sociais hegemônicos se estruturam. No discurso filmico de Tatuagem, se escancaram não apenas cus, mas toda uma engrenagem de disciplina e controle dos corpos que pode então ser questionada. Assim, todos que veem o filme e afetam-se com a performance do Chão de Estrelas podem, talvez, perceber a prisão na qual estão inseridos para manterem-se legítimos frente a uma lógica fascista que inviabiliza a circulação mais livre dos desejos, corpos e subjetividades. O discurso filmico de Tatuagem aponta assim uma possibilidade de abrir a prisão, "[..] y abrir la prision es abrir el ano del cuerpo social" (PRECIADO, 2009, p. 154), de forma que possamos perceber a abertura à multiplicidade que nos proporciona pensar, como nos convida o filme, que "a única coisa que nos salva, a única coisa que nos une, a única utopia possível é a utopia do cu"..

\section{Referências}

AUSTIN, John Langshaw. Quando dizer é fazer - palavras e ação. Porto Alegre: Artes médicas, 1990.

BARROS, Eduardo Portanova. O cinema brasileiro na pós-retomada: entre o imaginário autoral e a realidade figurativa. Esferas, ano 3, N.4, pp. 183-91, jan.-jun. 2014.

BRANHAM, R. Bracht. Desfigurar a moeda. A retórica de Diógenes e a invenção do cinismo. In: GOULET-CAZÉ, Marie-Odile; BRANHAM, R. Bracht. Os cínicos - o movimento cínico na Antiguidade e seu legado. São Paulo: Edições Loyola, 2007, pp. 95-119.

BUTLER, Judith. Problemas de gênero: feminismo e subversão de identidade. $2^{a}$ ed. 
Rio de Janeiro: Civilização Brasileira, 2008.

Cuerpos que importan: sobre loslímitesmateriales y discursivos del "sexo". Buenos Aires: Paidós, 2002.

Sovereign performatives in the contemporany scene of utterance. Critical Inquiry, Chicago, N²3, pp. 350-77, 1997.

COLLING, Leandro. Mais definições em trânsito: teoria queer. Disponivel em: <http://www.cult.ufba.br/maisdefinicoes/TEORIAQUEER.pdf>, acesso: 13/01/2016.

FOUCAULT, Michel. A coragem da verdade: curso no Collège de France (19831984). São Paulo: Editora WMF Martins Fontes, 2011.

O governo de si e dos outros: curso no Collège de France (1982-1983). São Paulo: Editora WMF Martins Fontes, 2010.

DELEUZE, Gilles; GUATTARI, Félix. O Anti-Édipo: capitalismo e esquizofrenia 1. São Paulo: Ed. 34, 2010.

DIAS, Rafael Parente Ferreira. A importância da felicidade na filosofia cínica. Griot Revista de Filosofia, Bahia, Vol.10, N.2, pp. 216-25, dezembro 2014.

Diógenes e a Filosofia Cínica. 2011.93 p. Dissertação (Mestrado em Filosofia) - Universidade Gama Filho, Rio de Janeiro, 2011.

GARCÍA, David Córdoba. Teoría queer: reflexiones sobre sexo, sexualidad e identidad. Hacia una politización de la sexualidad. In: CÓRDOBA, David; SÁEZ, Javier; VIDARTE, Paco (org.). Teoría queer: políticas bolleras, maricas, trans, mestizas. $2^{\mathrm{a}} \mathrm{ed}$, España: Egales editorial, 2007, pp. 21-66.

GOULET-CAZÉ, Marie-Odile; BRANHAM, R. Bracht. Introdução. In: Os cínicos - o movimento cínico na Antiguidade e seu legado. São Paulo: Edições Loyola, 2007, pp. 11-38.

GROS, Frédéric. A parrhesia em Foucault. In: Foucault: a coragem da verdade. São Paulo: Parábola Editora, 2004, pp. 155-66.

KRUEGER, Derek. $O$ indecente e a sociedade. $O$ despudor de Diógenes na cultura imperial romana. In: GOULET-CAZÉ, Marie-Odile; BRANHAM, R. Bracht. Os cinicos - o movimento cínico na Antiguidade e seu legado. São Paulo: Edições Loyola, 2007, pp. 245-63.

LACERDA, Hilton (dir.), Tatuagem, o filme. Brasil, 2013. 
LONG, A.A. A tradição socrática: Diógenes, Crates e a ética helenística. In: GOULET-CAZÉ, Marie-Odile; BRANHAM, R. Bracht. Os cínicos - o movimento cínico na Antiguidade e seu legado. São Paulo: Edições Loyola, 2007, pp. 39-57.

LOPES, Denilson; NAGIME, Mateus. New queer cinema e um novo cinema queer no Brasil. In: MURARI, Lucas; NAGIME, Mateus. New queer cinema: cinema, sexualidade e política. São Paulo: Caixa Cultural, 2015, pp. $12-7$.

LOPES, Denilson. Cinema e Gênero. In: MASCARELLO, Fernando (org.). História do cinema mundial. Campinas-SP: Papirus, 2006, pp. 379-94.

LOURO, Guacira Lopes. Teoria queer - uma política pós-identitária para a educação. Estudos Feministas, Florianópolis, Vol. 9, N.2, pp. 541-53, 2001.

MISKOLCI, Richard. Teoria Queer: um aprendizado pelas diferenças. Belo Horizonte: Autêntica \& UFOP, 2012.

NAVIA, Luiz E. Diógenes, o cínico. São Paulo: Odysseus Editora, 2009.

NOGUEIRA, Amanda Mansur Custódio. A brodagem no cinema em Pernambuco. 2014. Tese (Doutorado em Comunicação)- Universidade Federal de Pernambuco, Pernambuco, 2014.

O novo ciclo do cinema em Pernambuco: a questão do estilo. 2009. Dissertação (Mestrado em Comunicação) - Universidade Federal de Pernambuco, Recife, 2009.

PELÚCIO, Larissa. Traduções e torções ou o que se quer dizer quando dizemos queer no Brasil?.Revista Periódicus, Salvador, Vol. 1, N.1, pp. 68-91, 2014.

PINTO, Joana Plaza. Performatividade radical: ato de fala ou ato de corpo?. Gênero, Niterói, Vol. 3, N.1, pp. 101-10, 2002.

PRECIADO, Beatriz. Terror Anal: apuntes sobre los primeros días de la revolución sexual. In: HOCQUENGHEN, Guy. El deseo homosexual. Espanha: Melusina, 2009, pp. 134-74.

SÁEZ, Javier. El contexto sociopolítico de surgimiento de la teoriaqueer. De la crisis del SIDA a Foucault. In: CÓRDOBA, David; SÁEZ, Javier; VIDARTE, Paco (org.). Teoría queer: políticas bolleras, maricas, trans, mestizas. $2^{a} \mathrm{ed}$, España: Egales editorial, 2007, pp. 67-76.

SÁEZ, Javier; CARRASCOSA, Sejo. Por el culo: políticas anales. $2^{a}$ ed., España: Egales editorial, 2011. 
SOTO, Patricio Jeria. Diógenes de Sínope. Una reflexión sobre la problemática del lenguaje filosófico. Byzantion Nea Hellás, Chile, N. 29, pp. 45-54, 2010.

SOUSA, Juan Horacio de Freitas de. El cinismo: Un elogio a la desvergüenza. Bajo Palabra - Revista de Filosofía, Madri,II Época, N. 7, pp. 301-11, 2012.

SOUZA, Fábio Feltrin de; BENETTI, Fernando José. Historiografando a Abjeção: Uma Arqueografia dos Estudos Queer no Brasil (1990 - 2000). Contemporâneos: revista de artes e humanidades [online], São Paulo, N.12, pp. 01-13, 2015. Disponivel em: <http://www.revistacontemporaneos.com.br/n12/artigos/historiografandoabjecao.pdf>, acesso em 13/01/16.

WELLAUSEN, S. S.. Michel Foucault - parrhesia e cinismo. Tempo Social (USP. Impresso), São Paulo, Vol. 8, N.1, p. 113-125, 1996.

Recebido em julho de 2018.

Aprovado em dezembro de 2018. 